\title{
Assessing the social acceptance of key technologies for the German energy transition
}

\author{
Dorothee Baur ${ }^{1}$, Philip Emmerich², Manuel Johann Baumann ${ }^{1}$ and Marcel Weil ${ }^{1,3^{*}}$ (])
}

\begin{abstract}
Background: The widespread use of sustainable energy technologies is a key element in the transformation of the energy system from fossil-based to zero-carbon. In line with this, technology acceptance is of great importance as resistance from the public can slow down or hinder the construction of energy technology projects. The current study assesses the social acceptance of three energy technologies relevant for the German energy transition: stationary battery storage, biofuel production plants and hydrogen fuel station.

Methods: An online survey was conducted to examine the public's general and local acceptance of energy technologies. Explored factors included general and local acceptance, public concerns, trust in relevant stakeholders and attitudes towards financial support.

Results: The results indicate that general acceptance for all technologies is slightly higher than local acceptance. In addition, we discuss which public concerns exist with regard to the respective technologies and how they are more strongly associated with local than general acceptance. Further, we show that trust in stakeholders and attitudes towards financial support is relatively high across the technologies discussed.

Conclusions: Taken together, the study provides evidence for the existence of a "general-local" gap, despite measuring general and local acceptance at the same level of specificity using a public sample. In addition, the collected data can provide stakeholders with an overview of worries that might need to be addressed when planning to implement a certain energy project.
\end{abstract}

Keywords: Technology acceptance, Energy transition, Sustainability, Hydrogen fuel station, Battery storage, Biofuel production plant

\section{Background}

In June 2021, the German Federal Government agreed on an amendment to the Climate Change Act, aiming for climate neutrality by 2045 . Pulling forward the previous target by 5 years, the government aims to reduce emission by $65 \%$ by 2030 and introduced a new target of an $88 \%$ reduction by 2040 . These ambitious targets also affect the $\mathrm{CO}_{2}$ reduction targets in individual sectors, including the transport, energy and building sector up

\footnotetext{
*Correspondence: marcel.weil@kit.edu

${ }^{1}$ Institute for Technology Assessment and Systems Analysis (ITAS), Karlsruhe Institute of Technology (KIT), Karlsruhe, Germany

Full list of author information is available at the end of the article
}

to 2030 [1]. To reach the German Federal Government's goal of achieving net-zero $\mathrm{CO}_{2}$ emissions until 2045, an increased use of renewable energies, efficient energy use as well as sector coupling are necessary [2]. To facilitate the integration of renewable energy sources and to ensure a stable provision of energy to industry and society, the energy system transformation relies on new and emerging technologies. Even though technical factors ultimately determine to which degree different sectors can be decarbonized, non-technical factors such as cost, potential environmental impacts, regulation, public acceptance and consumer choices will determine the level of actual progress [3]. In line with this, the current study focuses on assessing citizen's perception of original author(s) and the source, provide a link to the Creative Commons licence, and indicate if changes were made. The images or other third party material in this article are included in the article's Creative Commons licence, unless indicated otherwise in a credit line to the material. If material is not included in the article's Creative Commons licence and your intended use is not permitted by statutory regulation or exceeds the permitted use, you will need to obtain permission directly from the copyright holder. To view a copy of this licence, visit http://creativecommons.org/licenses/by/4.0/. The Creative Commons Public Domain Dedication waiver (http://creativeco mmons.org/publicdomain/zero/1.0/) applies to the data made available in this article, unless otherwise stated in a credit line to the data. 
three energy technologies by examining their public acceptance. While active acceptance or public support [4] of emergent technologies can facilitate political support and incentivize industry and government to invest further in their development $[5,6]$, opposition to new technologies can result in project delays or even cancelling entire energy infrastructure projects [7].

Generally, representative opinion polls show that the public is in favor of the energy transition and new energy technologies in Germany [8]. However, resistance sometimes arises when concrete projects are to be realized, such as in the case of power lines or wind farms [9-11]. In the past, this phenomenon of people approving of energy technologies in general while opposing local energy infrastructure projects has been referred to as the "not in my backyard" (nimby) phenomenon [12, 13]. Recent research has proven nimby explanations to be too simplistic to explain the motivations for opposition to energy projects [14], and has put forward some recommendations to examine whether a general-local gap actually exists, which we will outline further below.

The present research was conducted within the Helmholtz "Energy System 2050" initiative, which explores the integration of technological key elements into the energy system and develops solutions to integrate the fluctuating renewable energies such as wind or solar power successfully into German and European energy systems. The objective of the work was to gain insights into the acceptance of energy storage technology as well as technologies for energy carrier utilization. More specifically, three technologies that are discussed in the Climate Action Program 2030 by the German government [15] are studied:

- grid-scale stationary battery storage systems,

- biofuel production plants and

- hydrogen refueling stations.

To better understand the public's view of these new technologies, both general and local acceptance are assessed. Additionally, we assess key variables that have been shown to influence public acceptance, namely trust in stakeholders, public concerns and attitudes towards financial support for the technologies. By doing so, we will (1) assess whether a general-local gap exists with regard to the three energy technologies chosen and (2) assess how public concerns are related to acceptance. Below, we first briefly introduce the technologies that are in focus of the current study by reviewing current energy system scenarios. Subsequently, we introduce factors relevant for the social acceptance of energy technologies.

\section{Emerging technologies in the energy sector}

Energy scenarios, which describe possible future developments of the energy system, can help to discern under which conditions and with which measures the goals as laid out in the Climate Change act can be achieved. More specifically, energy scenarios help to explore which technology options (and combinations) as well as regulatory measures can significantly contribute to the achievement of climate targets.

Germany's ambitious emission reduction targets cannot be achieved equally well in all sectors [16]. For instance, reducing emissions in the industrial sector will be more difficult than in the electric power sector. The electric power sector currently accounts for a large share of energy-related $\mathrm{CO}_{2}$ emissions in Germany [3]. To date, the focus for decarbonizing the power sector has been on increasing the share of renewable energies. Achieving this will require better integration in the electricity, heat and transport sector, infrastructure changes as well as the development of storage technologies to mitigate power intermittency of renewable energy sources $[3,16]$. While up to a share of around $40-60 \%$ of renewable energy, the need for increased flexibility in the German electricity system can be covered by flexibility options other than new electricity storage, full integration of renewables into the electricity system is increasingly more difficult when the share of renewables increases further [17]. With renewables averaging a share of $47.5 \%$ of electricity production in August 2021 [18], the need for new energy storage will increase over the next years. Currently, the majority of installed large-scale energy storage comprises pumped hydro-storage power [19]. Given the fact that pumped hydro-storage facilities alone cannot cover the amount of needed storage capacity alone, the need for increased storage capacity will have to be (partly) covered by a mixture of storage technologies such as battery storage, thermal storage or hydrogen covering different services. Battery storage is expected to play an increasingly important role in adapting the grid on a decentral level when connecting new renewables such as wind and solar power plants to smooth out production peaks [17, 20], and the market for battery storage is expected to grow, with annual additions of storage capacity by battery storage being expected to overtake annual additions by pumped hydro-storage by 2023 [21]. Given the fact that battery storage is expected to play an increasingly important role in the energy transition, grid-scale battery storage will be one of the technologies in focus of the current study.

With regard to renewables, wind energy, solar energy and biomass currently play a key role in the German energy system. Most scenario analyses expect especially on- and offshore wind and solar energy to cover 
the largest share of the total energy consumption in the future [3, 22-24]. The use of biomass on the other hand is debated since it is not regarded as justifiable to grow crops as biomass for energy production due to competition for arable land and potential negative environmental impacts [20,22]. In line with this, many scenario analyses expect only biomass that comes from waste and residues to be used in the future, which is why the contribution of biomass as an energy source is considered limited in the future energy system [22, 23]. Even though significant differences exists with regard to the expected share of bioenergy in the energy system, biomass and biofuels are nevertheless expected to be continued to be used to a certain extent, as the direct use of electricity from renewable energy is not the most efficient and environmentally friendly way of supplying energy in all consumption sectors $[25,26]$. In the mobility sector and industry, liquid or gaseous energy carriers will probably remain necessary, a demand that will likely partly be met by biomass. In line with this, one of the technologies studied in the current paper are biofuel production plants.

A second energy carrier that is expected to significantly contribute to meeting the demand for fuel and raw materials in the industrial and mobility sectors is hydrogen [3, 22, 27]. As outlined in Germany's hydrogen strategy [27], only hydrogen that has been produced using renewable energy (green hydrogen) is considered to be sustainable. Up to date, green hydrogen is not yet widely used, but is expected to be established as a decarbonization option. For instance, green hydrogen could replace the fossilbased hydrogen that is currently used in many chemical and industrial processes. In addition, hydrogen is expected to play a key role for sector coupling as well as a fuel in transport. As the public will likely be exposed to hydrogen infrastructure in the transport sector the most, we investigate the acceptance of hydrogen refueling stations as one of the key technologies in the current study. Below, we will discuss the three chosen technologies in more detail and shortly review past research on the social acceptance of the technologies.

\section{Stationary battery storage systems (SBS)}

Large-scale energy storage is essential for the successful implementation of the energy transition as it can mitigate the fluctuating output from renewable energy by storing excess electricity that is produced and by discharging it when demand is high $[28,29]$. This way, energy storage systems enable an increased share of renewable energies in the electrical grid while simultaneously increasing the resilience and security of supply at the local level [30, 31]. This can reduce, defer or prevent a cost-intensive and locally undesirable expansion of the electricity grid [32, 33]. France's grid operator RTE for instance is piloting the use of battery storage as virtual power lines, aiming to reduce the need to build new transmission lines by storing excess wind and solar power in batteries [34, 35]. Overall, research on the acceptance of battery storage systems is still relatively sparse, which emphasizes the necessity to conduct research on the acceptance of the technology. Most existing studies indicate that people hold positive attitudes towards battery storage technologies overall [36-39]. On the other hand, qualitative research also points towards the fact that there are various public concerns with regard to the technology that might decrease acceptance of battery storage in a local context [37]. More specifically, participants perceived battery storage as inappropriate on some landscapes, raised concerns about the loss of living space due to the technology and mentioned the risk of fire and explosion as safety concerns. Due to the nature of the qualitative research, it however remains unclear how public concerns and general and local acceptance relate to each other, which calls for a more thorough investigation of acceptance on different levels.

\section{Biofuel production plants}

To date, biomass is one of the most important and flexible renewable energy source in Germany. Regionally available biomass is used in solid, liquid and gaseous form to generate electricity and heat and to produce biofuels, making biomass a very versatile energy carrier. This way, the use of bioenergy can contribute to ensuring energy supply security and compensate for fluctuations caused by other renewable energy sources [40]. Furthermore, biofuels can play a valuable role in reducing carbon dioxide emissions and are often considered as carbon emission neutral [41, 42], as the carbon dioxide that is released when biofuels are burned is equal to the carbon dioxide that is absorbed by the biomass during its growth [43]. With biofuels having gained increasing importance in the field of renewable energies, analyzing its public importance is a key issue. For biofuel projects, local opposition is an issue that can cause project delays and interrupt operations $[44,45]$. Residents living nearby a biofuel production plant oftentimes report having to put up with odor and noise emissions induced by the plant $[46,47]$, which can influence acceptance.

\section{Hydrogen fuel stations}

The German national hydrogen strategy [27] assigns hydrogen a key role in facilitating the energy transition. By replacing fossil fuel use in transport, the use of hydrogen as an energy carrier can reduce air pollution in cities and the dependence on fossil fuels, provided that electrical energy from renewable energy sources such as wind energy or solar power is used for production 
via electrolysis [48]. The main advantage of hydrogen is that once produced and stored, it can generate electrical power in a fuel cell, emitting only water vapor and warm air instead of harmful carbon dioxide and nitrogen oxide emissions. Also, hydrogen can be used as an intermediate energy carrier for various power to $\mathrm{x}$ paths to produce, e.g., methane, methanol or ammonia [49]. However, the production, storage and use of hydrogen still requires great efforts and large investments in the necessary technology infrastructure before it can be rolled out on a wide scale [50]. Thus, hydrogen is currently still a very expensive energy carrier to use in industrial settings [51]. With regard to research on citizen's perception of hydrogen, studies report low public awareness and knowledge of hydrogen and associated technologies such as fuel cells [52] and inconsistent results with regard to the acceptance of hydrogen technologies. While some studies suggest that there is widespread support for hydrogen's development as a fuel and concerns with safety risks are rather low [53], other studies report hydrogen technologies such as hydrogen fuel stations receiving opposition or low acceptance from citizens [54-56]. More specifically, studies showed that people have mixed attitudes concerning the safety and storage of hydrogen near residential areas [54], that intentions to act against hydrogen facilities is more strongly based on moral considerations than on self-interest [55] and that the further the distance between fuel station and dwelling, the more accepting people are of the technology [56].

\section{Exploring factors influencing the acceptance of energy technologies}

Previous studies on the acceptance of energy technologies have shown that factors such as perceived risks and benefits, trust, perceived fairness and personal norms influence attitudes and behaviors towards technologies [57-61]. In the following, we will shortly introduce the factors examined in the current study.

\section{General vs local acceptance}

Public acceptance is a key factor in the diffusion of sustainable energy technologies [62]. While active acceptance or public support of emergent technologies can facilitate political support and incentivize industry and government to invest further in their development [4, 5], opposition to new technologies can result in project delays or even cancelling entire energy infrastructure projects [6]. Various definitions and understandings exist with regard to the term "acceptance", with some studies referring to attitudes when talking about acceptance [63], while other studies refer to attitudes as "acceptability". In the current study, we define the term acceptance as attitudes towards a technology, which some previous studies have referred to as "acceptability" [57]. Acceptance of energy technology can be assessed on both a general and local level. Acceptance on a general level is sometimes referred to as socio-political acceptance and encompasses acceptance of technologies and policies by the public, by key stakeholders and by policy-makers [64]. In the current study, we will focus on acceptance of technologies by the public. General acceptance is usually assessed as the general attitude towards an energy technology, which is what is most commonly measured in public opinion polls [65]. However, as energy projects have shown, general acceptance is not necessarily predictive of local acceptance of energy projects and resistance towards technologies can occur despite surveys indicating that a technology is generally approved of. In line with this, the relationship between general and local acceptance has been the subject of some discussion within research, with critics arguing that using representative opinion poll data to indicate acceptance towards a technology is painting a skewed picture [65]. Similarly, other research argues that even though people may be inclined to express positive attitudes towards renewables, this does not necessarily indicate their actual opinion about the issue [13]. Furthermore, local acceptance may be much more dependent on case- and project-specific variables, instead of general attitudes towards an energy technology [66]. Additionally, some research critique that many studies that examines the "general-local gap" or "national-local gap" as they call it oftentimes draws upon two non-correspondent dimensions [14]. More specifically, acceptance or attitudes towards energy technologies in general are usually examined at a public or national level, which are then compared with the local level, namely acceptance or attitudes towards energy technologies near the place where people live (e.g., a specific town). To determine whether a general-local acceptance gap actually exists, the authors recommend to measure responses regarding general and local acceptance at the same level of specificity, a suggestions that we adopt in the current study. The authors furthermore suggest adopting a place-based perspective rather than a spatial perspective when assessing local acceptance using a local sample. In this way, studies could better focus on how individuals and groups living in different places make sense of energy infrastructures and respond to it by taking into account their relationships with and feelings about those places. As we only measure acceptance using a national/public sample in the current study to assess general acceptance and acceptance of technologies close to people's homes at the same level of specificity, this recommendation does not concern the measures in the current study. Last, the authors suggest assessing more than simply attitudes towards energy technologies and to include other additional 
variables such as trust or the perceived outcomes of energy infrastructures when consulting a national/public sample. We follow this recommendation and explain our choice of further variables below.

\section{Public concerns}

Research has shown that perceived risks and benefits play an important role when it comes to public acceptance of technologies [57, 67-69]. Most studies examine risks and benefits on a rather general level, such as by asking respondents how useful, positive or safe they judge the technologies [70]. Risks and benefits assessed in this way have been shown to be (in)directly associated with general and local energy technology acceptance [70, 71]. Some studies however recommend placing the focus on specific costs and benefits perceived by local residents when studying the local acceptance of energy technologies [47] as local acceptance can be much more dependent on project-specific variables [66]. For instance, in the case of biogas, unpleasant smells are a cost associated with local acceptance [47], whereas for wind energy, the visual impacts of the technology have been shown to be associated with local acceptance [72]. In line with this reasoning, we assess which specific public concerns are perceived with regard to the three technologies and examine whether they are more strongly associated with local compared to general acceptance.

\section{Trust in stakeholders}

When technologies are still relatively unknown, public acceptance is strongly influenced by trust in stakeholders, as lay judgements of a technology may be based on assessments of those who are responsible for the technology and who are deemed technical experts [73, 74]. Generally, trust in stakeholders responsible for the technology is associated with higher acceptance of the technology. Several studies have examined the role of trust in stakeholders and have found that it can influence acceptance via both perceived risks and benefits of a technology as well as affective responses towards a technology. For instance, a study on hydrogen systems found that people who had a negative evaluation of trust in stakeholders and negative affective spontaneous associations perceived more risks and fewer benefits of the technology [75]. Similarly, a study on the acceptance of $\mathrm{CO}_{2}$ storage found that people's attitudes towards the technology were mainly based on trust and affective reactions [73].

\section{Attitudes towards financial support/funding}

Last, we will examine attitudes towards financial support/ funding. Technologies that receive funding or financial support from the government are more likely to be rolled out on a broader scale in the future. Therefore, assessing attitudes for financial support can serve as another indicator towards support for new technologies. As attitudes towards financial support/funding are examined on a general level (i.e., not for an energy project in a certain location), we expect attitudes towards financial support/ funding to be associated with general acceptance but not local acceptance.

\section{Methods}

We created an online survey to examine the factors that influence the social acceptance of energy technologies. First, the participants received a one-page description of one of the technologies, including a picture of the technology. This way, we wanted to ensure that participants had a common knowledge base to evaluate the technologies. Subsequently, different factors that may influence energy technology acceptance were examined. Explored factors included public concerns, knowledge about the technologies, perceived problems of the current energy system, trust in industry and municipality, affect, and environmental self-identity. In the current paper, we will report results on the factors public concerns, trust in stakeholders (industry and municipality), financial support and acceptance (general and local). Additionally, we assessed both general and public acceptance of the three technologies. All items were answered on 5-point Likert scales. Data were collected by distributing the survey via the open scientific survey panel "SoSci Panel" as well as social media channels. The survey was completed by 1247 participants, with the participants being about equally distributed across the three technologies (hydrogen fuel stations $n=409$, biofuel production plants $n=416$ and stationary battery storage $n=422$ ).

\section{Measurements}

Public concerns Public concerns with regard to the three energy technologies were measured with one question [Which of the effects listed below do you fear when using such systems?]. Based on input from expert interviews as well as the literature, seven public concerns were included as answer possibilities, with an additional open text field to mention any additional concerns [electrosmog, odor pollution, noise pollution, air pollution, fire hazard, risk of explosion, negative impact on the landscape or urban landscape, other-if you fear "other" effects under the previous question, you are welcome to tell us about them.]. The same answer options were presented independent of which technology the participants were asked to evaluate. This way, we wanted to ensure not to steer the participants by only providing concerns commonly associated with a certain technology.

Attitude towards financial support Attitudes towards financial support for the technologies were measured 
with one item [I approve that such plants are financially supported], which was answered on a 5-point Likert scale [ $1=$ strongly disagree, $5=$ strongly agree $]$.

Trust in stakeholders Trust in industry was measured with three items: I trust that the governmental authorities will: (1) ensure that safe technology plants will be built; (2) have the relevant expertise to successfully build a safe technology plant; (3) will operate the plant safely [ $1=$ strongly disagree, $5=$ strongly agree]. Trust in municipality was measured with four items: I trust that the governmental authorities will (1) take the concerns of residents into account; (2) make a responsible decision on whether or not to build the technology; (3) ensure that safe technology plants will be built; (4) execute safety checks to ensure the safe operation of the plant [ 1 = strongly disagree, $5=$ strongly agree $]$.

Acceptance General acceptance was measured with the item "Overall, I rate such systems as..." [1=very negative, $5=$ very positive], whereas local acceptance was measures with the item "I have no problem with the construction of such a facility next to my place of residence." $[1=$ strongly disagree, $5=$ strongly agree $]$. In this way, we measure general and local acceptance at the same level of specificity when using a national/public sample, as recommended by Batel and Devine-Wright [14].

\section{Results}

\section{Socio-demographic profile}

Out of 1247 respondents, $52 \%$ were male and $47 \%$ female, the gender of $1 \%$ of the respondents is unknown. Most of the participants had a high educational level, $67 \%$ had attained a university degree and $23 \%$ had completed high school. About half of the participants were in employment (55\%), while students represented the second most frequently named profession (21\%). The median category given for age was $40-49$ years (see Fig. 1). As the sample contained a large share of participants holding a university degree, the data are not fully representative of the German population in this regard [76].

\section{Public concerns}

The most frequently mentioned concerns differed with regard to the nature of the respective technologies (see Fig. 2). For stationary battery storage systems, the most
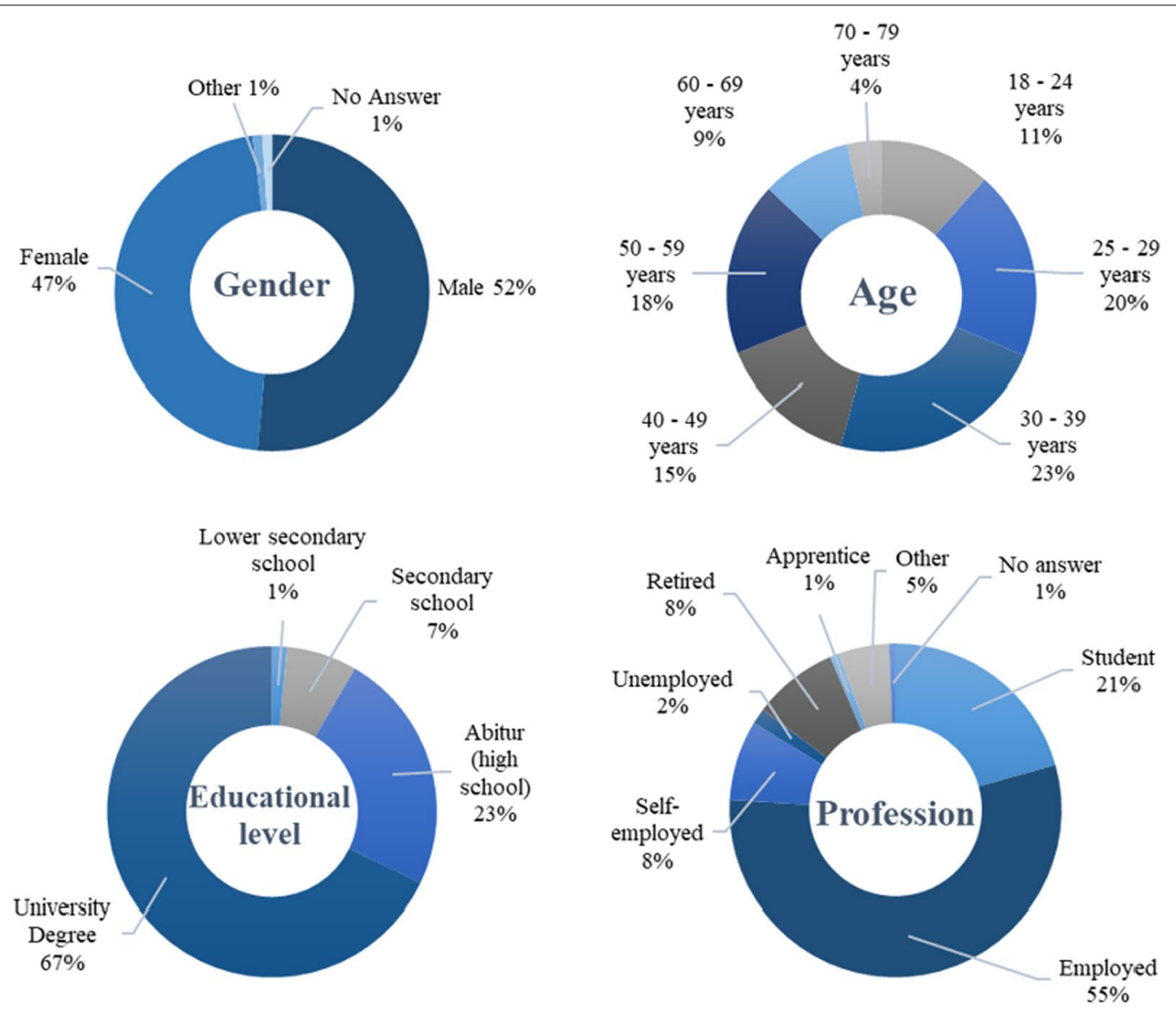

Fig. 1 Participants'socio-demographic profile 


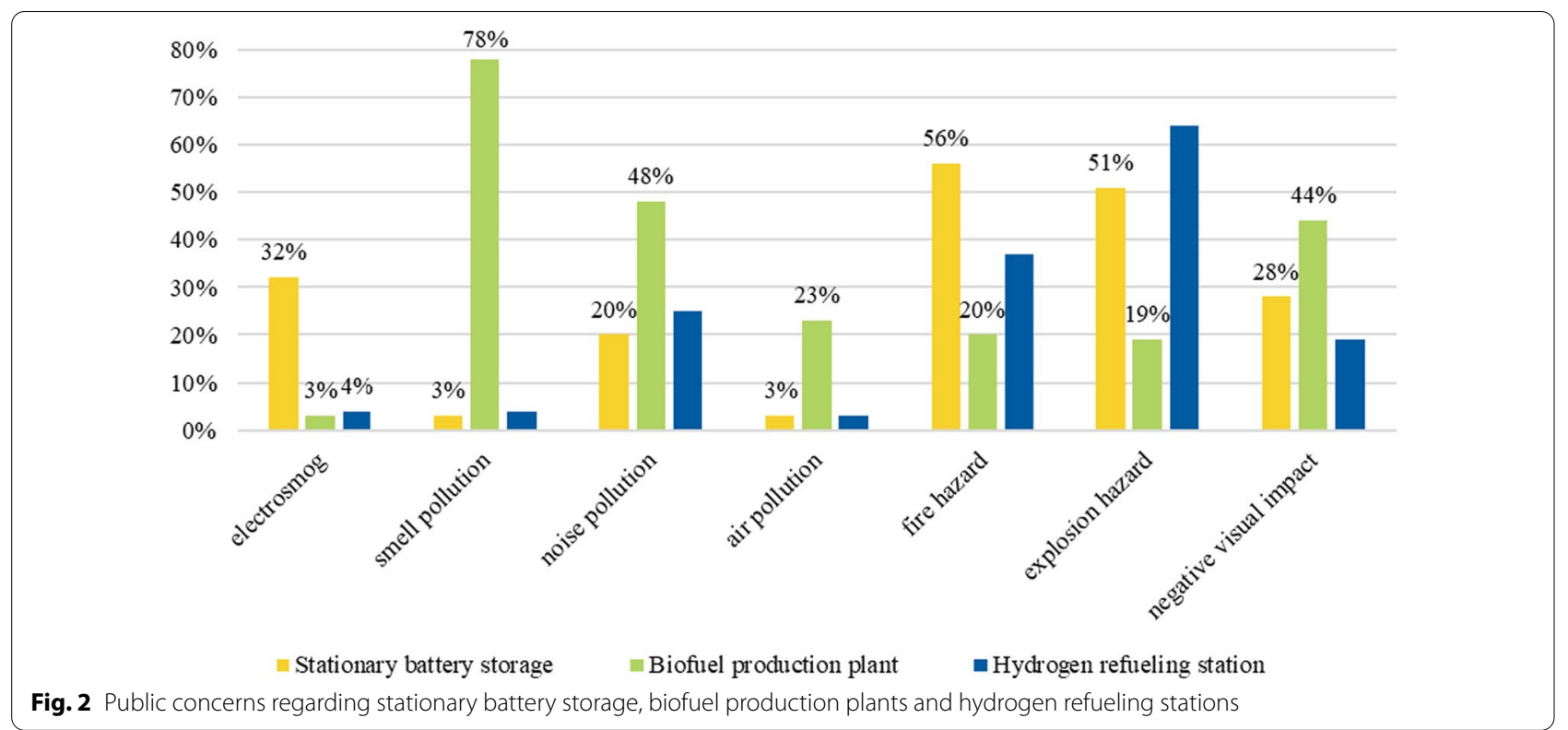

frequently mentioned concerns included fire hazards (56\%) and explosion hazards (51\%). About a third of the participants were also concerned about electrosmog (32\%) and of battery storage plants having a negative impact on the landscape and cityscape (28\%). The least frequently mentioned concerns included noise pollutions (20\%), smell pollution (2\%) and air pollution (2\%). Additional concerns that were provided by the participants in the empty text field included concerns about the environmental impact of the technology (production and disposal, unsustainable raw materials, impairment of for a and fauna), concerns about costs related the use of the technology (disposal costs, decline in land and property values, high taxes) as well as safety and health concerns, which were related to the answer possibilities already provided (health risks from electromagnetic fields, severe fires and toxic smoke, risk of accidents). With regard to biofuel production plants, over two-thirds of the participants were concerned about smell pollution (78\%), whereas the second most frequently mentioned concerns included noise pollution (48\%) and a negative impact on the landscape and cityscape (44\%). Air pollution (23\%), explosion hazards $(20 \%)$ and fire hazards $(19 \%)$ were mentioned as concerns about equally often, while electrosmog (3\%) was only mentioned by a small percentage of the participants. Additional concerns that were provided by the participants in the empty text field included concerns about the costs related to the use of the technology (increased land prices and prices of other biomass product such as animal feed and food, monopolization of arable land), environmental concerns (pollution of land, water and air due to high methane load and the import of biomass from tropical forests, endangerment of natural humus formation), concerns related to traffic (increased traffic volume leading to higher air and nose pollution and overcrowded roads) as well as concerns related to land use and the usefulness of the technology (cultivation of crops for biomass will lead to an imbalance in the use of raw materials, monocultures and competition with organic food production).

With regard to hydrogen refueling stations, explosion hazards (64\%) and fire hazards (37\%) were the most frequently mentioned concerns. Furthermore, about a quarter of the participants mentioned noise pollution (25\%) and a negative impact on the landscape and cityscape (19\%) as concerns, whereas electrosmog (4\%), smell pollution (4\%) and air pollution (3\%) were barely mentioned as concerns. Additional concerns that were provided by the participants in the empty text field included concerns about the costs related to the use of the technology (high production costs of hydrogen, failing property values), environmental concerns (consequences on the water economy, noise pollution, threat to flora and fauna, consequences of the haze and increased humidity), safety concerns (target for terrorist attacks, risk of explosion), as well as concerns regarding the usefulness of the technology (use of fossil fuels for hydrogen production, continuation of current transport concept with emphasis on individual transport).

\section{Trust in stakeholders}

With regard to trust in stakeholders, the majority of respondents across the three technologies indicated to trust the industry and municipalities (see Fig. 3). While 


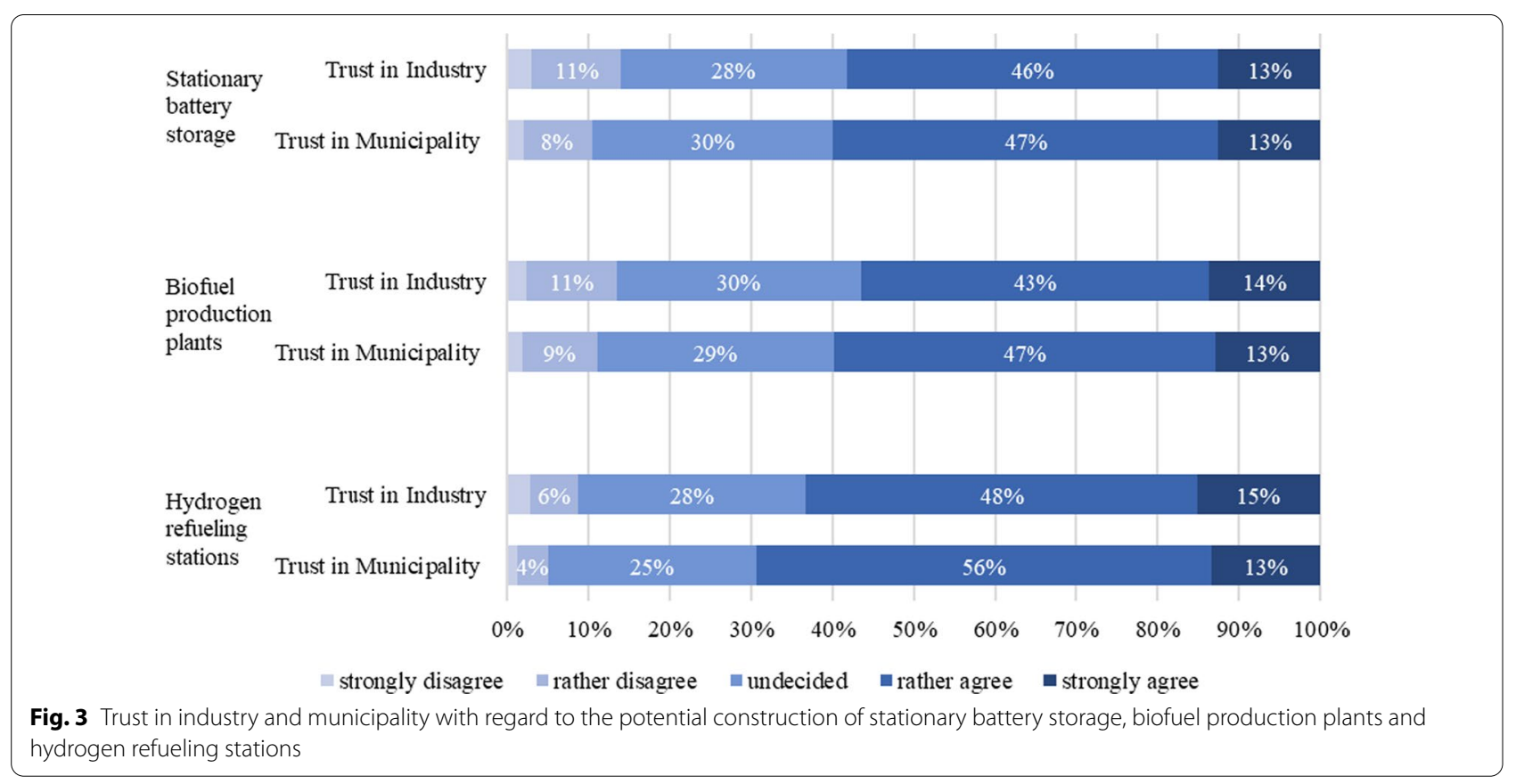

the percentages of participants who indicated to strongly agree ranged between 13 and 15\% for both trust in industry and municipality across the technologies, around 50\% of participants indicated to rather agree with regard to trusting the industry ( $46 \%$ for stationary battery storage, $43 \%$ for biofuel production plants, $48 \%$ for hydrogen refueling stations) and municipality (47\% for stationary battery storage, $47 \%$ for biofuel production plants, $56 \%$ for hydrogen refueling stations). Relatively few respondents indicated not to have trust in the industry and municipalities. Noticeably, a rather large share of participants seemed to be undecided about whether they trusted the relevant stakeholders. With regard to trust in industry, $28-30 \%$ of participants indicated to be undecided about whether they trusted industry stakeholders $(28 \%$ for stationary battery storage, $30 \%$ for biofuel production plants, $28 \%$ for hydrogen refueling stations). With regard to trust in municipalities, the percentages were very similar, with $25-30 \%$ of participants indicating to be undecided (30\% for stationary battery storage, $29 \%$ for biofuel production plants, $25 \%$ for hydrogen refueling stations).

\section{Attitude towards financial support}

Most participants had rather positive attitudes towards financial support for the three technologies (see Fig. 4). For stationary battery storage, the majority of respondents either strongly (45\%) or rather agreed (30\%) to the technology to be financially supported. For biofuel production plants, $18 \%$ of respondents strongly agreed to the technology to be financially supported, whereas $50 \%$ rather agreed to this. Last, for hydrogen refueling stations, $28 \%$ of respondents were strongly in favor of financial support towards the technology, while $51 \%$ were rather in support of this. For all three technologies, only few respondents (less than 10\%) were against the technologies receiving financial support. About $12-18 \%$ of respondents indicated to be undecided about whether the technologies should be financially supported.

\section{Public acceptance of emerging technologies}

Overall, the three technologies were evaluated as fairly positive, meaning that general acceptance of all three technologies is high (see Fig. 5). With regard to stationary battery storage, $37 \%$ of the participants indicated to perceive the technology as very positive. Biofuel production plants were evaluated as very positive by $16 \%$ of the participants, whereas hydrogen refueling stations were rated as very positive by $25 \%$ of the participants. Furthermore, for all three technologies, about half of the participants evaluated the technologies as rather positive ( $48 \%$ for stationary battery storage systems, $58 \%$ for biofuel production plants, $50 \%$ for hydrogen refueling stations). Only few participants indicated to perceive the technologies negatively. For both biofuel production plants and hydrogen refueling stations, about a fifth of the participants were undecided with regard to the technologies (17\% for biofuel production plants, $20 \%$ for hydrogen refueling stations). With regard to stationary battery storage, only $10 \%$ of respondents indicated to be undecided about the technology. 


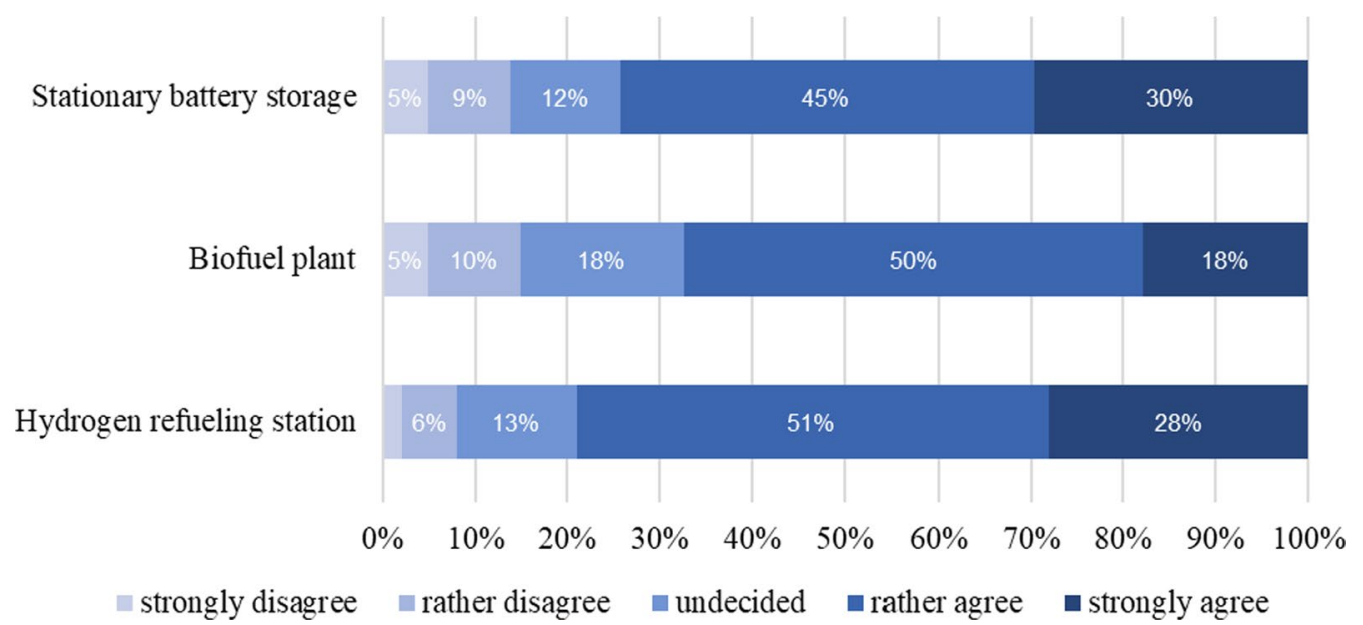

Fig. 4 Attitudes towards financial support for the three energy technologies stationary battery storage, biofuel production plants and hydrogen refueling stations

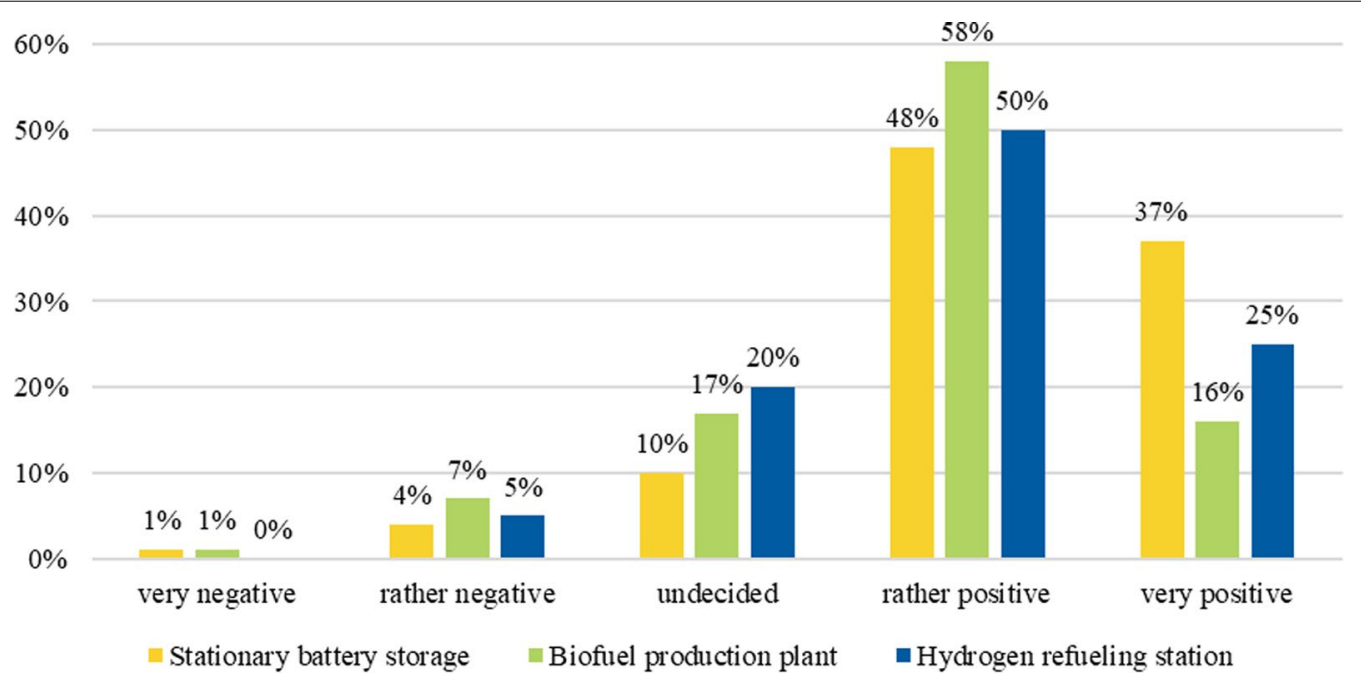

Fig. 5 General acceptance of stationary battery storage, biofuel production plants and hydrogen refueling stations

When asking the participants whether they would accept the technology to be placed near their homes (local acceptance), the participant's responses were slightly less positive than when asked about whether they would accept the technologies in general (see Fig. 6). With regard to stationary battery storage systems, $37 \%$ strongly agreed to accept the technologies to be placed close to their homes, for biofuel production plants, $16 \%$ strongly agreed and for hydrogen refueling stations, $25 \%$ strongly agreed. Furthermore, around $40 \%$ of the participants indicated to rather agree to this (39\% for stationary battery storage systems, $41 \%$ for biofuel production plants, $42 \%$ for hydrogen refueling stations). Between 9 and $18 \%$ of the participants indicated to rather disagree with regard to the technologies being placed close to their homes (13\% for stationary battery storage systems, $18 \%$ for biofuel production plants, and $9 \%$ for hydrogen refueling stations). Only a small percentage of participants strongly disagreed with having one of the technologies in the vicinity of their homes. Last, with regard to all three technologies, about a fifth of the participants were undecided about whether they would accept the technologies close to their homes $(21 \%$ for stationary battery storage systems, $21 \%$ for biofuel production plants, and $20 \%$ for hydrogen refueling stations). 


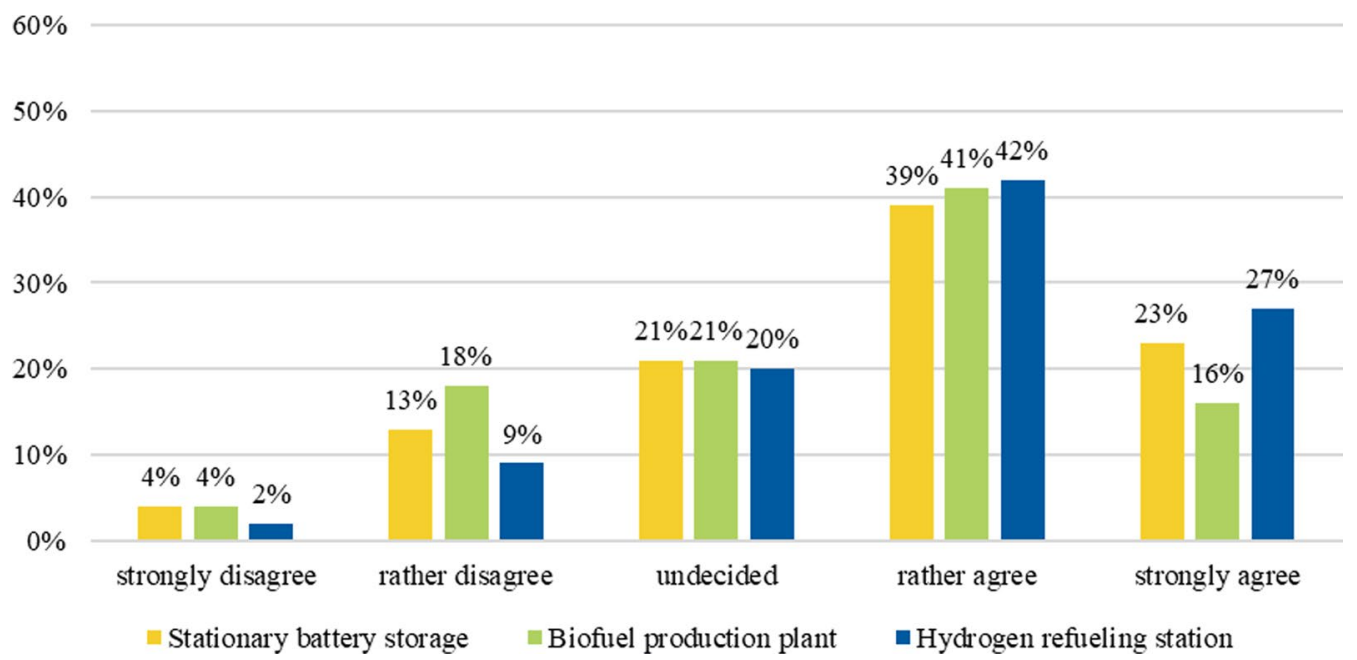

Fig. 6 Local acceptance of stationary battery storage, biofuel production plants and hydrogen refueling stations

Table 1 Bivariate correlations (Spearman's rank order) between public concerns and financial support, general acceptance and local acceptance for stationary battery storage

\begin{tabular}{lll}
\hline & General acceptance & Local acceptance \\
\hline Electrosmog & -0.002 & $-0.338^{* *}$ \\
Smell pollution & -0.044 & -0.073 \\
Noise pollution & -0.048 & $-0.176^{* *}$ \\
Air pollution & -0.088 & $-0.145^{* *}$ \\
Fire hazard & $-0.114^{*}$ & $-0.125^{*}$ \\
Explosion hazard & -0.074 & $-0.204^{* *}$ \\
Negative impact on land- & -0.081 & $-0.235^{* *}$ \\
scape and cityscape & & $0.217^{* *}$ \\
Financial support & $0.595^{* *}$ & $0.361^{* *}$ \\
General acceptance & - & \\
\hline
\end{tabular}

${ }^{*} p<0.05$

${ }^{* *} p<0.01$

\section{Associations between public concerns, public acceptance and financial support}

To look at the relationship between public concerns and acceptance, Spearman's rank correlation coefficients were examined. No associations between public concerns and general acceptance were found, except for few weak associations $\left(r_{\mathrm{s}}<0.2\right)$ that are not reported in detail here. On the other hand, some moderate associations $\left(r_{\mathrm{s}}>0.2\right)$ between public concerns and local acceptance were found. For stationary battery storage systems, moderate association between local acceptance and electrosmog $\left(r_{\mathrm{s}}=-0.338, p<0.001\right)$, explosion hazard $\left(r_{\mathrm{s}}=-0.204, p<0.001\right)$ and negative impact on the landscape and cityscape $\left(r_{\mathrm{s}}=-0.235\right.$,
Table 2 Bivariate correlations (Spearman's rank order) between public concerns and financial support, general acceptance and local acceptance for biofuel production plants

\begin{tabular}{lll}
\hline & General acceptance & Local acceptance \\
\hline Electrosmog & -0.006 & $-0.120^{*}$ \\
Smell pollution & $0.114^{*}$ & -0.059 \\
Noise pollution & 0.039 & $-0.171^{* *}$ \\
Air pollution & $-0.125^{*}$ & $-0.241^{* *}$ \\
Fire hazard & 0.001 & -0.064 \\
Explosion hazard & 0.026 & -0.048 \\
Negative impact on land- & -0.054 & $-0.294^{* *}$ \\
scape and cityscape & & $0.345^{* *}$ \\
Financial support & $0.604^{* *}$ & $0.380^{* *}$ \\
General acceptance & - & \\
\hline
\end{tabular}

${ }^{*} p<0.05$

${ }^{* *} p<0.01$

$p<0.001$ ) were found (see Table 1). For biofuel production plants, moderate association between local acceptance and air pollution $\left(r_{\mathrm{s}}=-0.241, p<0.001\right)$ as well as negative impact on the landscape and cityscape $\left(\mathrm{r}_{\mathrm{s}}=-\right.$ $0.294, p<0.001$ ) were found (see Table 2). For hydrogen refueling stations (see Table 3 ), the only moderate association between local acceptance and a public concern was found for explosion hazard $\left(r_{\mathrm{s}}=-0.223, p<0.001\right)$.

Additionally, we examined the correlations between public acceptance and financial support for the energy technologies. Across all technologies, financial support and general acceptance were strongly correlated $\left(r_{\mathrm{s}}=0.595, p<0.001\right.$ for stationary battery storage systems, $r_{\mathrm{s}}=0.604, p<0.001$ for biofuel production plants, 
Table 3 Bivariate correlations (Spearman's rank order) between public concerns and financial support, general acceptance and local acceptance for hydrogen refueling stations

\begin{tabular}{lll}
\hline & General acceptance & Local acceptance \\
\hline Electrosmog & $-0.132^{* *}$ & $-0.150^{* *}$ \\
Smell pollution & -0.095 & $-0.106^{*}$ \\
Noise pollution & -0.060 & $-0.114^{*}$ \\
Air pollution & $-0.154^{* *}$ & $-0.128^{* *}$ \\
Fire hazard & -0.053 & $-0.153^{* *}$ \\
Explosion hazard & -0.069 & $-0.223^{* *}$ \\
Negative impact on land- & $-0.107^{*}$ & $-0.156^{* *}$ \\
scape and cityscape & & $0.340^{* *}$ \\
Financial support & $0.560^{* *}$ & $0.333^{* *}$ \\
General acceptance & - & \\
${ }^{*} p<0.05$ & & \\
${ }_{* *}^{* *} p<0.01$ & &
\end{tabular}

and $r_{\mathrm{s}}=0.560, p<0.001$ for hydrogen refueling stations). Furthermore, financial support was moderately correlated with local acceptance $\left(r_{\mathrm{s}}=0.217, p<0.001\right.$ for stationary battery storage systems, $r_{\mathrm{s}}=0.345$, $p<0.001$ for biofuel production plants, and $\mathrm{r}_{\mathrm{s}}=0.340$, $p<0.001$ for hydrogen refueling stations).

\section{Discussion}

The current study supports and extends findings with regard to common public concerns about the three technologies studied: stationary battery storage, biofuel production plants and hydrogen refueling stations. The most frequently mentioned concerns with regard to stationary battery storage include fire and explosion hazards, followed by electrosmog and the technology having a negative impact on the landscape and cityscape. These results go in line with previous results from a qualitative study conducted in the UK [37], which mentioned fire and explosion hazards as well as electromagnetic radiation as perceived risks. The study also reports that stationary battery storage systems may be more acceptable if situated out of the way or if the technology fit in with the environment, a finding that is consistent with participants in our study indicating to be concerned about the negative impact of the technology on the landscape or cityscape. About a fifth of the participants in our study mentioned noise pollution as a concern, a finding that was not reported in previous studies. An additional concern that was mentioned by some participants in the open text field included environmental impacts, more specifically with regard to the raw materials and production and disposal of the technology, which is a concern that was also found in the study by Thomas, Demski and Pidgeon [37]. With regard to biofuel production plants, the most commonly mentioned concern in our study was smell pollution, followed by noise pollution and the technology having a negative impact on the landscape and cityscape. These concerns go in line with previous studies conducted in Switzerland and Austria. In a study on the local acceptance of existing biogas plants in Switzerland [47], the authors found that smell perception influences acceptance indirectly via perceived benefits and risks as well as trust. Furthermore, results of a study based on expert interviews indicate that low acceptance of biogas plants in Austria is related to complaints about high levels of smell, noise and traffic by residents, which can result in planned projects having to be scaled down or shut down [77]. A concern not commonly reported in previous studies was biofuel production plants having a negative impact on the landscape. Potentially, the visual impact of energy infrastructure increasingly concerns citizens as more and more new energy infrastructure is introduced as the energy transition progresses. For hydrogen fuel stations, the most frequently reported concerns were explosion hazards and fire hazards, followed by noise pollution and the technology having a negative impact on the landscape and cityscape. Especially the risk of explosion is a commonly reported safety concern in studies on hydrogen acceptance [52, 78], with hydrogen often being associated with explosions and fire. As a lack of trust in safety is associated with opposition to hydrogen infrastructures, such concerns need to be taken very seriously during the planning process of the technology.

With regard to public acceptance, our results suggest that for all three technologies, general acceptance is slightly higher than local acceptance. These results go in line with previous findings, which indicate that even though some surveys report people approving of new energy technologies [8], public opposition oftentimes arises when concrete energy infrastructures are intended to be built [9-11]. The finding that general and local acceptance differ has important implications, as it underlines the importance of distinguishing these concepts when studying public acceptance. Public opinion surveys usually measure acceptance on a general level, which can create a skewed picture of technology acceptance if one assumes that data on general acceptance will directly translate into acceptance on a local level [65]. When asked on a general level, people may be inclined to express positive attitudes towards sustainable energy technologies [13]. However, this not necessarily express their actual opinion on the issue, which might differ when asked about acceptance of technologies close to one's home. Importantly, the current study shows that there is a gap between general and local acceptance, even if it is assessed at the same level of specificity (i.e., measuring general and local acceptance at the same level 
of specificity using a public/national sample). In other words, the results indicate that people can relate to the issue even if they are not directly affected, but merely asked to provide their opinion about a fictional situation.

Public concerns were shown to be associated with local acceptance, but not with general acceptance besides a few exceptions. Associations between public concerns and local acceptance differed per technology. Even though causality cannot be assumed due to the nature of the study, the results can nevertheless provide an indication of the specific concerns that may inhibit local acceptance of the technologies and lead to opposition when specific energy infrastructure projects are planned. This way, public concerns can be addressed upfront and trust in safety measures can be built. In addition, these results point towards the fact that it might be helpful to include more specific concerns in future studies, as to date, mostly risks on a general level are included in most research [70].

Trust in industry and stakeholders was high across all three technologies. What was noticeable about trust in stakeholders was that across all technologies and for both trust in industry and stakeholders, a relatively large share of respondents (30\%) indicated to be undecided about whether they trusted the stakeholders. As previous research has shown that trust in stakeholders is an important predictor of acceptance [73, 74], this is a relevant issue in need of further analysis. Attitudes towards financial support of the three energy technologies were relatively high across all the technologies. As expected, financial support and general acceptance were correlated across all three technologies. This finding goes in line with previous research on climate engineering technologies, which also reports a strong correlation between support for further research and support for deployment of technologies [79]. As the majority of studies focuses predominantly on the predictors of public acceptance of energy technologies, future research could explore whether similar factors, such as perceived benefits of the technology, are associated with attitudes towards financial support of energy technologies.

\section{Conclusion and policy recommendations}

In the current study, we aimed to examine the social acceptance of three emerging energy technologies: stationary battery storage, biofuel production plants and hydrogen refueling stations. In light of this, we assessed public concerns, acceptance (general and local), trust in stakeholders, as well as financial support for the technologies. Following the recommendations by Batel and Devine-Wright [14], we assessed acceptance of technologies in general as well as acceptance of technologies close to people's homes at the same level of specificity, using a public/national sample in the current study. Similarly to the results of Batel and Devine-Wright, we did see a difference with regard to general and local acceptance, despite only referring to a fictional scenario with regard to local acceptance in our study. Overall, the results indicate that acceptance of all three technologies was fairly high in general, which was also reflected in the participant's attitudes for financial support. Local acceptance of the technologies was slightly lower, but no pattern of strong opposition could be seen. This indicates that even though participants were not "directly" affected by the placement of energy technologies close to their homes, they could still relate to the issue. In other words, even though the study indicates that there is a gap between general and local acceptance, this finding disputes the prevalent representation of energy users as nimbys, namely people who are selfish, irrational and only concerned with issues around energy technologies when they are affected directly "in their own backyards". In practice, these results illustrate the added value that surveys into the public acceptance of technologies can provide, even if people who do not have direct experience with a certain energy technology are surveyed. As it can be time-consuming to consult local samples, we recommend assessing general and local acceptance using public/national sample as a first step to gauge whether there are indications for local opposition towards technologies. Should such a study indicate that this can be the case, consulting a local sample would then be a feasible second step when planning energy infrastructure in a certain community or town. In line with this, this approach would also be helpful to assess potential public concerns that can influence acceptance at a local level, a similar approach can be adopted. Using a public/national sample, assessing public concerns by means of a survey can provide stakeholders with an overview regarding worries that might need to be addressed when planning to implement a certain energy project. Once a clear picture exists with regard to the public concerns that exist among the public with regard to certain new energy technologies, further measures can be taken to address the concerns identified. As shown in our study, some of the public concerns that emerged are unlikely to happen in real life. As public concerns are associated with local acceptance, we suggest these to be addressed upfront with the help of transparent communication efforts. This way, misconceptions about the technologies and associated costs and risks could be prevented. Nevertheless, it needs to be kept in mind that information provision, which is a public form of public involvement, is not necessarily sufficient to secure public support. In addition, even though we consider knowledge about public concerns as vital to planning energy projects, policy-makers and practitioners should refrain 
thinking of energy infrastructure plans as "top-down" processes that the public should seemingly accept. On the contrary, if valid public concerns exist, these should be taken seriously. Previous research shows that even though public involvement is not an easy remedy with regard to acceptance issues surrounding energy projects, acceptance may be higher if people believe that the decision-making process is fair, and if they feel that their interests are considered [59]. On the other hand, if people feel as if their concerns are not actually heard, public involvement can even backfire and dampen acceptance [81].

\section{Limitations and avenues for future research}

Despite the exploitation of a large dataset, the current study is subject to a number of limitations. With participants of certain age groups, professions and educational background being overrepresented, the sample is not fully representative of the German population. Furthermore, with regard to assessing local acceptance, we presented the participants with a fictional situation. The results obtained in the current study are helpful in some ways, but also are subject to a drawback. While the results provide support for the existence of a general-local acceptance gap even when measuring acceptance at the same level of specificity which shows that people still relate to issues around energy projects [14], people's reactions to the implementation of the technologies might still deviate in real life when using a local sample. For instance, there could be a degree of response bias, as potential risks and drawbacks of having one of the technologies built in the vicinity of people's home might be of even stronger personal relevance in real life than when answering to an imagined situation in a survey. Future studies could compare general and local acceptance using both national/public and local samples of participants who are faced with the implementation of a concrete energy project close to their homes, ideally before and after the energy infrastructure is built. This would enable to better understand how results regarding local acceptance are influenced by the research design and sample used in a study. In line with this, public concerns related to specific energy technologies and their influence on local acceptance could as well be examined in more detail. In the current study, we include specific concerns instead of simply measuring whether perceived risks at a general level influence acceptance. While we think that this approach taken has some advantages over simply measuring perceived risks in general, future studies could use qualitative method to more thoroughly understand people's concerns through a "place-based" lens. For instance, what does it mean to them when the new technology $\mathrm{X}$ is introduced in their community? How do they expect the new technology to affect their community? Do they have specific place-related worries that affect their perception of the new technology? Gaining an understanding of people's perception in this way could help to better manage how a specific energy project needs to be planned and adapted to a certain community. With regard to trust in stakeholders, a relatively large share of participants indicated to be undecided about whether they trusted the stakeholders in the current study. As it is unclear whether this is due to the fact of some of the technologies being relatively unknown, future studies could explore which factors influence trust, such as knowledge about the technologies. Additionally, it would be interesting to examine whether technological incidents affect trust in different stakeholders. In line with this, future studies could explore whether trust in stakeholders changes in the long term after technological incidents happen, but also whether technological incidents with regard to similar technologies influences trust and thereby acceptance. For instance, it would be interesting to examine whether fire incidents related to battery electric vehicles (BEVs) not only affect attitudes and trust towards BEVs, but also towards other battery technologies, such as battery storage. In conclusion, future studies can extend our knowledge about best practices in terms of using both public and local samples when assessing the social acceptance of energy technologies as well as factors influencing acceptance.

\section{Acknowledgements \\ For their support in developing the survey, we would like to thank Prof. Michael Braun from GESIS—Leibniz Institute for the Social Sciences, Dr. Dominik Leiner and Dr. Christina Peter, both from the Ludwig Maximilian University of Munich; our thanks also go to the platform SoSci-survey (www. soscisurvey.de) for hosting the survey.}

\section{Authors' contributions}

DB: validation, data analysis, data curation, data visualization, writing —original draft, writing — review and editing. PE: conceptualization, methodology, validation, data analysis, investigation, data curation, writing — review and editing, supervision, project administration. MJB: conceptualization, investigation, resources, writing - review and editing, supervision, funding acquisition. MW: conceptualization, investigation, resources, writing — review and editing, supervision, funding acquisition. All authors read and approved the final manuscript.

\section{Funding}

Open Access funding enabled and organized by Projekt DEAL. The authors would like to thank the Helmholtz Association initiative 'Energy System 2050' for financial support. Our special thanks go to the researchers of the initiative, who have supported the work in several ways. This work also contributes to the research performed at CELEST (Center for Electrochemical Energy Storage Ulm-Karlsruhe). This work was partially funded by the Deutsche Forschungsgemeinschaft (DFG, German Research Foundation) under Germany's Excellence Strategy —EXC 2154-Project number 390874152 and the European Union's-H2020-LC-GD-2020 / H2020-LC-GD-2020-6 project stoRIES Grant Agreement No. 101036910. Content does not reflect the official opinion of 
the European Union. Responsibility for the information and views expressed herein lies entirely with the authors.

\section{Availability of data and materials}

All data generated or analyzed during this study are included in this published article and its supplementary information files: Emmerich P, Hülemeier A-G, Jendryczko D et al. (2020) Public acceptance of emerging energy technologies in context of the German energy transition. Energy Policy 142:111516. https:// doi.org/10.1016/j.enpol.2020.111516.

\section{Declarations}

\section{Ethics approval and consent to participate}

Approval by an ethics committee was not required. The aim of the online survey was to collect the participant's opinions on sustainable energy technologies and did not risk any potential harm to the participants, nor was there any intentional deception involved. Appropriate ethical aspects with regard to online surveys were taken into account: before starting the survey, informed consent was obtained from the participants. The participants were informed about the data being collected anonymously and about them being able to stop their participation at any point in time. At the end of the survey, participants were debriefed about the aims of the survey.

\section{Consent for publication}

Data were collected anonymously and the manuscript does not include details, images, or videos relating to an individual person.

\section{Competing interests}

The authors declare that they have no known competing financial interests or personal relationships that could have appeared to influence the work reported in this paper.

\section{Author details}

${ }^{1}$ Institute for Technology Assessment and Systems Analysis (ITAS), Karlsruhe Institute of Technology (KIT), Karlsruhe, Germany. ${ }^{2}$ Institute of Technology and Management, Technical University of Berlin, Berlin, Germany. ${ }^{3}$ HelmholtzInstitute UIm for Electrochemical Energy Storage (HIU), UIm, Germany.

\section{Received: 11 February 2021 Accepted: 19 December 2021}

\section{Published online: 11 January 2022}

\section{References}

1. Bundesministerium für Umwelt, Naturschutz und nukleare Sicherheit (2016) Klimaschutzplan 2050: Klimaschutzpolitische Grundsätze und Ziele der Bundesregierung. Available via BMU. https://www.bmu.de/filea dmin/Daten_BMU/Download_PDF/Klimaschutz/klimaschutzplan_2050_ bf.pdf. Accessed 4 Feb 2021

2. Sohre A (2013) Strategien in der energie- und klimapolitik. Springer, Wiesbaden

3. Shell (2017) Energy Scenarios Germany. Available via Shell. https://www. shell.com/energy-and-innovation/the-energy-future/scenarios/whatare-scenarios/_jcr_content/par/tabbedcontent/tab/textimage_25172 244.stream/1504104048141/87b2684f712f1 da82ef32d07b1955592041 2d451/shell-energy-scenarios-germany.pdf

4. Schweizer-Ries P (2008) Energy sustainable communities: environmental psychological investigations. Energy Policy 36:4126-4135. https://doi.org/ 10.1016/j.enpol.2008.06.021

5. Stimson J, Mackuen M, Erikson R (1995) Dynamic representation. Am Political Sci Rev 89:543-565. https://doi.org/10.2307/2082973

6. Bock S, Reimann B (2017) Beteiligungsverfahren bei umweltrelevanten Vorhaben. Abschlussbericht. Available via UBA. https://www.umwel tbundesamt.de/sites/default/files/medien/1410/publikationen/201705-30_texte_37-2017_beteiligungsverfahren-umweltvorhaben.pdf. Accessed 4 Feb 2021

7. Westdeutscher Rundfunk (2020) Baustopp für Windräder zwischen Altena und Neuenrade. Westdeutscher Rundfunk. Available via WDR. https:// www1.wdr.de/nachrichten/westfalen-lippe/baustopp-windraederaltena-100.html. Accessed 4 Feb 2021
8. Agentur für Erneuerbare Energien (2019) Wichtig für den Kampf gegen den Klimawandel: Bürger*innen wollen mehr Erneuerbare Energien. Agentur für Erneuerbare Energien e.V. Available via AEE. https://www. unendlich-viel-energie.de/themen/akzeptanz-erneuerbarer/akzeptanzumfrage/akzeptanzumfrage-2019. Accessed 4 Feb 2021

9. Schöpper Y (2020) Akzeptanz in der Fläche, Protest im Lokalen? Studie zur Windenergie an Land. Agentur für Erneuerbare Energien e.V. Available via AEE. https://www.unendlich-viel-energie.de/media/file/3801.AEE_ Renews_Spezial_90_Akzeptanz-Wind_Apr20.pdf. Accessed 4 Feb 2021

10. Asendorpf $D$ (2016) Klimaschutz mit Nebenwirkungen: Die hässliche Seite der Energiewende. https://www.swr.de/swr2/wissen/energiewen de-haesslich,broadcastcontrib-swr-31480.html. Accessed 21 Sept 2020

11. Schwenkenbecher A (2017) What is wrong with Nimbys? Renewable energy, landscape impacts and incommensurable values. Environ Values 26:711-732. https://doi.org/10.3197/096327117×15046905490353

12. Petrova M (2013) NIMBYism revisited: public acceptance of wind energy in the United States. Wiley Interdiscip Rev: Climate Change 4:575-601. https://doi.org/10.1002/wcc.250

13. van der Horst D (2007) NIMBY or not? Exploring the relevance of location and the politics of voiced opinions in renewable energy siting controversies. Energy Policy 35:2705-2714. https://doi.org/10.1016/j.enpol.2006.12. 012

14. Batel S, Devine-Wright P (2015) A critical and empirical analysis of the national-local 'gap' in public responses to large-scale energy infrastructures. J Environ Planning Manage 58(6):1076-1095. https://doi.org/10. 1080/09640568.2014.914020

15. Bundesregierung (2019) Klimaschutzprogramm 2030 der Bundesregierung zur Umsetzung des Klimaschutzplans 2050. https://www.bunde sregierung.de/resource/blob/975226/1679914/e01d6bd855f09bf05cf7 498e06d0a3ff/2019-10-09-klima-massnahmen-data.pdf?download=1. Accessed 4 Feb 2021

16. UBA (2010) Energy target 2050: 100\% renewable electricity supply. Available via UBA. https://www.umweltbundesamt.de/sites/default/files/ medien/378/publikationen/energieziel_2050_kurz.pdf. Accessed 16 Aug 2021

17. Agora Energiewende (2014) Electricity Storage in the German Energy Transition. Available via Agora Energiewende. https://www.agora-energ iewende.de/fileadmin/Projekte/2013/speicher-in-der-energiewende/ Agora_Speicherstudie_EN_web.pdf. Accessed 16 Aug 2021

18. Statista (2021) Anteil erneuerbarer Energien an der Stromerzeugung pro Monat in Deutschland von August 2020 bis August 2021. Available via Stastista. https://de.statista.com/statistik/daten/studie/779784/umfrage/ monatlicher-anteil-erneuerbarer-energien-an-der-stromerzeugung-indeutschland/ Accessed 15 Aug 2021

19. International Energy Agency (2018) Tracking clean energy processes. https://www.iea.org/topics/tracking-clean-energy-progress. International Energy Agency. Accessed 12 Nov 2020

20. BfN (2018) Naturverträgliche Energieversorgung aus 100\% erneuerbaren Energien 2050. Available via BfN. https://www.bfn.de/fileadmin/BfN/servi ce/Dokumente/skripten/Skript501.pdf. Accessed 15 Aug 2021

21. International Energy Agency (2019) Will pumped storage hydropower expand more quickly than stationary battery storage? https://www.iea. org/articles/will-pumped-storage-hydropower-expand-more-quicklythan-stationary-battery-storage. International Energy Agency. Accessed 4 Feb 2021

22. UBA (2013) Germany 2050 a greenhouse gas-neutral Country. Available via UBA. https://www.umweltbundesamt.de/sites/default/files/medien/ 376/publikationen/germany_2050_a_greenhouse_gas_neutral_count ry_langfassung.pdf. Accessed 16 Aug 2021

23. dena (2018) dena Study Integrated Energy Transition. Available via dena. https://www.umweltbundesamt.de/sites/default/files/medien/376/ publikationen/germany_2050_a_greenhouse_gas_neutral_country_ langfassung.pdf. https://www.dena.de/fileadmin/dena/Dokumente/Pdf/ 9283_dena_Study_Integrated_Energy_Transition.PDF. Accessed 16 Aug 2021

24. UBA (2019) Wege in eine ressourcenschonende Treibhausgasneutralität. Available via UBA. https://www.umweltbundesamt.de/sites/default/files/ medien/1410/publikationen/rescue_studie_cc_36-2019_wege_in_eine_ ressourcenschonende_treibhausgasneutralitaet_auflage2_juni-2021.pdf. Accessed 15 Aug 2021 
25. UBA (2021) System comparison of storable energy carriers from renewable energies. Available via UBA. https://www.umweltbundesamt.de/ sites/default/files/medien/5750/publikationen/2021-03-03_texte_402021_syseet_eng.pdf. Accessed 16 Aug 2021

26. ewi (2018) The energy market in 2030 and 2050-the contribution of gas and heat infrastructure to efficient carbon emission reductions. Available via ewi. https://www.ewi.research-scenarios.de/cms/wp-content/uploa ds/2017/11/ewi_ERS_Energy_market_2030_2050_web.pdf. Access 16 Aug 2021

27. Bundesministerium für Wirtschaft und Energie (2020) The National Hydrogen Strategy. Bundesministerium für Wirtschaft und Energie. Available via BMWi. https://www.bmwi.de/Redaktion/EN/Publikationen/Energ ie/the-national-hydrogen-strategy.pdf?_blob=publicationFile $\& v=6$. Accessed 4 Feb 2021

28. Schainker RB (2004) Executive overview: energy storage options for a sustainable energy future. In: IEEE Power Engineering Society General Meeting, Denver, CO, USA, 6-10 June 2004

29. Weil M, Tübke J (2015) Energiespeicher für energiewende und elektromobilität. TATuP Zeitschrift für Technikfolgenabschätzung in Theorie und Praxis 24:4-9. https://doi.org/10.14512/tatup.24.3.4

30. Panwar M, Chanda S, Mohanpurkar M et al (2019) Integration of flow battery for resilience enhancement of advanced distribution grids. Int J Electr Power Energy Syst 109:314-324. https://doi.org/10.1016/j.ijepes. 2019.01 .024

31. Zhou J, Tsianikas S, Birnie D, Coit D (2019) Economic and resilience benefit analysis of incorporating battery storage to photovoltaic array generation. Renewable Energy 135:652-662. https://doi.org/10.1016/j. renene.2018.12.013

32. Sterner M, Stadler I (2014) Energiespeicher-Bedarf, Technologien, Integration. Springer, Wiesbaden

33. Wietschel M, Plötz P, Pfluger B, Klobasa M, Eßer A, Haendel M, MüllerKirchenbauer J, Kochems J, Hermann L, Grosse B, Nacken L (2018) Sektorkopplung: Definition, Chancen und Herausforderungen. Working Paper Sustainability and Innovation.

34. IRENA (2020) Virtual power lines. International Renewable Energy Agency, Abu Dhabi

35. Colthorpe (2020) France's grid battery'experiments'take aim at creating market fit for carbon neutrality. Energy Storage News. https://www. energy-storage.news/news/frances-grid-battery-experiments-take-aimat-creating-market-for-carbon-neu. Accessed on 4 Feb 2021

36. Emmerich P, Hülemeier A, Jendryczko D et al (2020) Public acceptance of emerging energy technologies in context of the German energy transition. Energy Policy 142:111516. https://doi.org/10.1016/j.enpol.2020. 111516

37. Thomas G, Demski C, Pidgeon N (2019) Deliberating the social acceptability of energy storage in the UK. Energy Policy 133:110908. https://doi. org/10.1016/j.enpol.2019.110908

38. Jones C, Gaede J, Ganowski S, Rowlands I (2018) Understanding laypublic perceptions of energy storage technologies: results of a questionnaire conducted in the UK. Energy Procedia 151:135-143. https://doi.org/ 10.1016/j.egypro.2018.09.038

39. Gaede J, Jones C, Ganowski S, Rowlands I (2020) Understanding laypublic perceptions of energy storage technologies: preliminary results of a questionnaire conducted in Canada. Energy Rep 6:249-258. https://doi. org/10.1016/j.egyr.2020.03.031

40. Dinjus E, Dahmen N (2012) The Bioliq process concept, technology and state of development. Auto Tech Review 1(3):26-31. https://doi.org/10. 1365/s40112-012-0030-z

41. Johnson E (2009) Goodbye to carbon neutral: getting biomass footprints right. Environ Impact Assess Rev 29:165-168. https://doi.org/10.1016/j. eiar.2008.11.002

42. Timmons D, BuchholzT, Veeneman C (2016) Forest biomass energy: assessing atmospheric carbon impacts by discounting future carbon flows. GCB Bioenergy 8:631-643. https://doi.org/10.1111/gcbb.12276

43. Agentur für Erneuerbare Energien (2009) Globale Bioenergienutzung: Potentiale und Nutzngspfade. Agentur für Erneuerbare Energien e.V. Available via AEE. https://www.infothek-biomasse.ch/images//126_2009_ WBGU_Bioenergie_Potenziale_Nutzungspfade.pdf. Accessed 4 Feb 2021

44. Griesen M (2010) Akzeptanz von Biogasanlagen. In: Bonner Studien zur Wirtschaftssoziologie, 34th ed. Shaker, Aachen.
45. Upreti BR (2004) Conflict over biomass energy development in the United Kingdom: some observations and lessons from England and Wales. Energy Policy 32(6):785-800. https://doi.org/10.1016/S03014215(02)00342-7

46. Kortsch T, Hildebrand J, Schweizer-Ries P (2015) Acceptance of biomass plants-results of a longitudinal study in the bioenergy-region Altmark. Renewable Energy 83:690-697. https://doi.org/10.1016/j.renene.2015.04. 059

47. Soland M, Steimer N, Walter G (2013) Local acceptance of existing biogas plants in Switzerland. Energy Policy 61:802-810. https://doi.org/10.1016/j. enpol.2013.06.111

48. IRENA (2019) Hydrogen: a renewable energy perspective. International Renewable Energy Agency, Abu Dhabi

49. Gong J, English NJ, Pant D, Patzke GR, Protti S, Zhang T (2021) Power-to-X: lighting the path to a net-zero-emission future.

50. Robinius M, Linßen J, Grube T, Reuß M, Stenzel P, Syranidis K, Kuckertz P, Stolten D (2018) Comparative analysis of infrastructures: hydrogen fueling and electric charging of vehicles. Forschungszentrum Jülich, Jülich

51. Nazir H, Louis C, Jose S, Prakash J, Muthuswamy N, Buan MEM et al (2020) Is the $\mathrm{H} 2$ economy realizable in the foreseeable future? Part I: $\mathrm{H} 2$ production methods. Int J Hydrogen Energy 45(27):13777-13788. https://doi. org/10.1016/j.jijhydene.2020.03.092

52. Ricci M, Bellaby P, Flynn R (2008) What do we know about public perceptions and acceptance of hydrogen? A critical review and new case study evidence. Int J Hydrogen Energy 33(21):5868-5880. https://doi.org/10. 1016/j.ijhydene.2008.07.106

53. Achterberg $P$, Houtman $D$, Van Bohemen $S$, Manevska K (2010) Unknowing but supportive? Predispositions, knowledge, and support for hydrogen technology in the Netherlands. Int J Hydrogen Energy 35(12):60756083. https://doi.org/10.1016/j.jijhydene.2010.03.091

54. Zaunbrecher BS, Bexten T, Wirsum M, Ziefle M (2016) What is stored, why, and how? Mental models, knowledge, and public acceptance of hydrogen storage. Energy Procedia 99:108-119. https://doi.org/10.1016/j. egypro.2016.10.102

55. Hart D (2010) Strategic and socioeconomic studies in hydrogen energy. In: Stolten D (ed) Hydrogen and fuel cells. Wiley-VHC, Weinheim, pp $567-576$

56. Mumford J, Gray D (2009) Reconciling conflicting interpretations of risk. A case study about the siting of a hazardous plant. J Commun Manag 13(3):233-249. https://doi.org/10.1108/13632540910976680

57. Huijts NM, Molin EJ, Steg L (2012) Psychological factors influencing sustainable energy technology acceptance: a review-based comprehensive framework. Renew Sustain Energy Rev 16(1):525-531. https://doi.org/10. 1016/j.rser.2011.08.018

58. Perlaviciute G, Steg L (2014) Contextual and psychological factors shaping evaluations and acceptability of energy alternatives: integrated review and research agenda. Renew Sustain Energy Rev 35:361-381. https://doi.org/10.1016/.rser.2014.04.003

59. Steg L, Perlaviciute G, van der Werff E (2015) Understanding the human dimensions of a sustainable energy transition. Front Psychol 6:805. https://doi.org/10.3389/fpsyg.2015.00805

60. Perlaviciute G, Schuitema G, Devine-Wright P, Ram B (2018) At the heart of a sustainable energy transition: the public acceptability of energy projects. IEEE Power Energ Mag 16(1):49-55. https://doi.org/10.1109/MPE. 2017.2759918

61. Zoellner J, Schweizer-Ries P, Wemheuer C (2008) Public acceptance of renewable energies: results from case studies in Germany. Energy Policy 36(11):4136-4141. https://doi.org/10.1016/.enpol.2008.06.026

62. Kardooni R, Yusoff SB, Kari FB (2016) Renewable energy technology acceptance in Peninsular Malaysia. Energy Policy 88:1-10. https://doi.org/ 10.1016/j.enpol.2015.10.005

63. L'Orange Seigo S, Dohle S, Siegrist M (2014) Public perception of carbon capture and storage (CCS): a review. Renew Sustain Energy Rev 38:848-863. https://doi.org/10.1016/j.rser.2014.07.017

64. Wüstenhagen R, Wolsink M, Bürer MJ (2007) Social acceptance of renewable energy innovation: an introduction to the concept. Energy Policy 35(5):2683-2691. https://doi.org/10.1016/j.enpol.2006.12.001

65. Aitken M (2010) Why we still don't understand the social aspects of wind power: a critique of key assumptions within the literature. Energy Policy 38(4):1834-1841. https://doi.org/10.1016/j.enpol.2009.11.060 
66. Wolsink M (2012) Undesired reinforcement of harmful 'self-evident truths' concerning the implementation of wind power. Energy Policy 48:83-87. https://doi.org/10.1016/j.enpol.2012.06.010

67. Boudet HS (2019) Public perceptions of and responses to new energy technologies. Nat Energy 4(6):446-455. https://doi.org/10.1038/ s41560-019-0399-x

68. Devine-Wright $P(2008)$ Reconsidering public acceptance of renewable energy technologies: a critical review. In: Jamasb T, Grubb M, Pollitt M (eds) Delivering a low carbon electricity system: technologies, economics and policy. Cambridge University Press, Cambridge

69. Singleton $\mathrm{G}$, Herzog H, Ansolabehere S (2009) Public risk perspectives on the geologic storage of carbon dioxide. Int J Greenhouse Gas Control 3(1):100-107. https://doi.org/10.1016/j.jpggc.2008.07.006

70. Huijts NM, Molin EJ, van Wee B (2014) Hydrogen fuel station acceptance: a structural equation model based on the technology acceptance framework. J Environ Psychol 38:153-166. https://doi.org/10.1016/j.jenvp.2014. 01.008

71. Sonnberger M, Ruddat M (2017) Local and socio-political acceptance of wind farms in Germany. Technol Soc 51:56-65. https://doi.org/10.1016/j. techsoc.2017.07.005

72. Petrova MA (2016) From NIMBY to acceptance: toward a novel framework - VESPA — for organizing and interpreting community concerns. Renewable Energy 86:1280-1294. https://doi.org/10.1016/j.renene.2015. 09.047

73. Midden CJ, Huijts NM (2009) The role of trust in the affective evaluation of novel risks: the case of CO2 storage. Risk Anal 29(5):743-751. https://doi. org/10.1111/j.1539-6924.2009.01201.x

74. Siegrist M, Cvetkovich $G$ (2000) Perception of hazards: the role of social trust and knowledge. Risk Anal 20(5):713-720. https://doi.org/10.1111/ 0272-4332.205064

75. Montijn-Dorgelo FN, Midden CJ (2008) The role of negative associations and trust in risk perception of new hydrogen systems. J Risk Res 11(5):659-671. https://doi.org/10.1080/13669870801967218

76. Statistisches Bundesamt (2019) Society-Environment, Press Release No. 055 of February 2019. Available via destatis. https://www.destatis.de/EN/ Press/2019/02/PE19_055_213.html. Accessed 8 Feb 2021.

77. Brudermann T, Mitterhuber C, Posch A (2015) Agricultural biogas plants-a systematic analysis of strengths, weaknesses, opportunities and threats. Energy Policy 76:107-111. https://doi.org/10.1016/j.enpol.2014.11.022

78. O'Garra T, Pearson P, Mourato S (2007) Public acceptability of hydrogen fuel cell transport and associated refuelling infrastructures. In: Flynn R, Bellaby P (eds) Risk and the Public Acceptance of New Technologies. Palgrave, Basingstoke

79. Terwel BW, Harnick F, Ellemers N, Daamen DDL (2010) Voice in political decision-making: the effect of group voice on perceived trustworthiness of decision makers and subsequent acceptance of decisions. J Exp Psychol 16(2):173-186. https://doi.org/10.1037/a0019977

\section{Publisher's Note}

Springer Nature remains neutral with regard to jurisdictional claims in published maps and institutional affiliations.

Ready to submit your research? Choose BMC and benefit from:

- fast, convenient online submission

- thorough peer review by experienced researchers in your field

- rapid publication on acceptance

- support for research data, including large and complex data types

- gold Open Access which fosters wider collaboration and increased citations

- maximum visibility for your research: over 100M website views per year

At BMC, research is always in progress.

Learn more biomedcentral.com/submissions 